\title{
THE PENELOPIAD: A VOZ FEMININA E O REVISIONISMO CRÍTICO DA TRADIÇÃO
}

Juliana Cristina Terra de Souza

Resumo: O presente artigo objetiva analisar brevemente como The Penelopiad (2005) da escritora canadense Margaret Atwood, dialoga e revisa a Odisseia de Homero. Buscar-se-á apontar de que forma Atwood ressignifica os episódios, desarticulando a figura do herói épico e revisando, na perspectiva de Adrienne Rich (1972), as imagens cristalizadas em torno do feminino criadas pela tradição literária ocidental. Através de duas vozes narrativas, que põem em xeque, ao mesmo tempo, a benevolência de Penélope e o episódio do enforcamento das doze escravas, The Penelopiad traz a tomada da pena pela mulher não apenas como possibilidade da construção da identidade e experiência feminina, mas também, enquanto uma problematização da própria categoria "mulher". As manifestações literárias, enquanto práticas sociais, estão conectadas com o momento histórico da sua emergência. A dupla narração na obra de Atwood, desempenha um papel na constituição da estrutura da narrativa e se relaciona com a multiplicidade do ser mulher na contemporaneidade. O externo se torna interno, como dispõe Antonio Candido (2011).

Palavras-chave: Re-visão. Odisseia. The Penelopiad.

Abstract: This article aims to briefly analyze how The Penelopiad (2005) by Canadian writer Margaret Atwood, dialogues and reviews Homer's Odyssey. We will try to point out how Atwood re-signifies the episodes, dismantling the figure of the epic hero and re-targeting, in the perspective of Adrienne Rich (1972), the crystallized images around the feminine created by western literary tradition. Through two narrative voices, which call into question, at the same time, Penelope's benevolence and the episode of the hanging of the twelve slaves, The Penelopiad brings the taking of the pen by the woman not only as a possibility of the construction of feminine identity and experience, but also, as a problematization of the category of "woman" itself. Literary manifestations, as social practices, are connected with the historical moment of their emergence. The double narration in Atwood's work plays a role in constituting the structure of the narrative and is related to 
the multiplicity of being a woman in contemporary times. The external becomes internal, as stated by Antonio Candido (2011).

Keywords: Re-vision. Odissey. The Penelopiad.

\section{INTRODUÇÃO: O REVISIONISMO CRÍTICO E A TRADIÇÃO PATRIARCAL}

Empreender uma comparação entre textos produzidos em épocas e, portanto, contextos sócio-históricos diferentes requer que se considere que a literatura não foge às contingências de seu momento de produção. O texto literário, enquanto produto cultural, vincula-se às características psicológicas e sociais de seu tempo. Isso posto, há também que se levar em conta que uma obra literária que efetua uma nova leitura da tradição, ainda que se configure como produto autônomo de sentido, deve ser analisada sem perder de vista a relação que estabelece com a sua matriz de origem.

A análise comparada que se pretende efetuar ao longo desse trabalho segue o pressuposto de que qualquer relacionamento com uma matriz que produz novos sentidos efetua uma mácula na tradição e constitui-se enquanto algo original. O que será buscado é entender como Margaret Atwood, autora de The Penelopiad, dialoga com a Odisseia, e quais são os sentidos que cria e os que desarticula em sua releitura, divergindo significativamente da tradição, 
ainda que tendo o mesmo enredo como pano de fundo. A narrativa de Atwood se vale das histórias homéricas e comanda a relação que estabelece entre o velho e o novo através de um viés crítico e revisionista. A tradição presente em The Penelopiad, portanto, como postula Laurent Jenny, já não fala: ela é falada - "deixa de denotar, para conotar" (1979, p. 22).

Em seu famoso ensaio When we dead awaken: writing as revision, a poeta e crítica literária feminista Adrienne Rich fala sobre a prática da revisão da tradição - re-visão - no texto de autoria feminina. Rich entende a re-visão como uma atividade que é principalmente crítica.

$\mathrm{O}$ ato de olhar para trás, de ver com novos olhos, de entrar em um texto antigo a partir de uma nova direção crítica - é para nós mais que um capítulo da história cultural: é um ato de sobrevivência. Até podermos entender os pressupostos nos quais estamos mergulhadas nós não conseguiremos conhecer a nós mesmas. E esse impulso para o autoconhecimento, para a mulher, é mais que uma busca de identidade: é parte de sua recusa à autodestrutividade da sociedade dominada pelo homem. Uma crítica radical à literatura, feminista em seu impulso, tomaria o trabalho sobretudo como uma pista de como vivemos, como temos vivido, como temos sido levadas a imaginarmos a nós mesmas, como nossa língua nos aprisionou e também nos libertou; e como 
podemos começar a ver - e então a viver de novo. (1972, p. 18, tradução nossa)

A fim de melhor entender a especificidade da noção de re-visão proposta por Rich - pensada especialmente para o texto de autoria feminina -, é fundamental explicitar que não se trata da ideia tradicional de revisão. Revisionismo é, como definido por Harold Bloom, "um redirecionamento ou uma segunda visão, que leva a uma reestimativa ou uma avaliação" e o revisionista é aquele que "se esforça por ver outra vez, de modo a estimar e avaliar diferentemente, de modo a então direcionar 'corretivamente'" (2003, p. 24, grifos do autor). Se revisar é, nessa perspectiva, ver novamente e, com base nisso, efetuar uma estimativa e avaliação, ambos os conceitos podem parecer, em um primeiro momento, fazer referência à mesma coisa - o ver outra vez algo e criar a partir disso -; entretanto, a especificidade da re-visão de Rich é falar sobre um determinado tipo de revisão: a fim de poder ter um conhecimento de si e então escrever de forma plena -, a escritora deve conhecer primeiro as premissas masculinas em torno do feminino presentes na arte e na cultura, que inundam a vida de todas elas, pois, por ser produto de cultura, os mitos e as imagens presentes na sociedade as afetam (RICH, 1972, p. 18-19).

Para além de olhar para trás, vislumbrando o que o homem ditou sobre o feminino (pautado em imagens do que 
ele espera da mulher), a re-visão implica, segundo Rich, "se voltar contra algo que nega tudo o que ela é" (1972, p. 21, tradução nossa), vendo de uma forma nova a fim de poder gerar a crítica desses discursos. Somente lutando com a imagem das mulheres na produção artística dos homens, e criando a partir dessa luta - desta forma, um tipo especial de re-visão - é que as mulheres poderiam recusar ser no presente o que os homens sempre fizeram delas na tradição.

As críticas literárias feministas Sandra Gilbert e Susan Gubar, em seu The Madwoman in the Attic, estudam o processo de revisão empreendido pelas escritoras, desde o século XIX, numa perspectiva similar ao que é proposto por Rich. De acordo com Gilbert e Gubar, pelo fato de a mulher ter conhecido a si mesma historicamente através do que leu nos escritos dos homens - que negam o que ela sabe e sente de si -, o revisionismo dos textos patriarcais visa a uma leitura crítica que possibilite a superação dos estereótipos do feminino na criação artística dessas mulheres. A luta das escritoras contra o silêncio imposto é seguida da revisão das poéticas patriarcais (GILBERT; GUBAR, 2000, p. 47). O processo de revisão que marca o desenvolvimento da nova tradição literária de autoria feminina, portanto, não deixa de ser uma forma de subversão. Desse modo, se toda re-visão é uma revisão, nem toda revisão será um ato de re-visão. 
Essa visão relaciona-se com o percurso empreendido pela própria crítica feminista. Elaine Showalter, no ensaio "Towards a feminist poetics", desenvolve o que define como sendo "uma breve taxonomia, se não uma poética, da crítica feminista" (1979, p. 25, tradução nossa), visando contribuir para os estudos de língua inglesa. Ela reconhece a existência de duas variedades distintas dentro da crítica feminista e as descreve minuciosamente ao longo do ensaio. No primeiro momento, ocorreu um movimento em torno do estudo do modo como os escritores homens falavam das mulheres em suas obras. Depois disso, a crítica avançou e a mulher tornouse, de fato, o foco: o objeto de estudo tornou-se o texto escrito por mulheres. Showalter nomeia ambas as fases. A primeira é a fase feminista, a pesquisa sobre as falsas imagens da mulher construídas na literatura e a comparação com a mulher "real". A seguinte é a fase da ginocrítica, por volta de 1975, quando o primeiro modelo perde sua força, e as críticas feministas buscam uma nova postura crítica pautada na escrita de mulheres, apesar de o primeiro modelo ainda resistir. A ginocrítica se interessa pela mulher enquanto escritora e por questões tais quais a criatividade e a linguagem feminina, a trajetória da carreira literária da mulher escritora, bem como sobre o estudo de escritoras e trabalhos específicos (SHOWALTER, 1979, p. 25-26). 
A proposta do re-vision de Adrienne Rich transita por ambas as formas descritas por Showalter - em nível artístico e crítico - já que a artista é por si mesma a crítica dos textos patriarcais, alguém que efetua uma leitura crítica dos postulados deles para criar a sua arte. A atuação da escritora - ao re-visar as poéticas patriarcais - ao mesmo tempo em que resgata a experiência dessas mulheres também visa a desarticular as formas literárias patriarcais através desse resgate.

Quando lidamos com textos de revisionismo crítico da tradição só é possível apontar a subversão - que se dá por meio da re-visão de que fala Adrienne Rich - "se relacionarmos (a obra) com seus arquétipos - por sua vez abstraídos de longas séries de textos, de que constituem, por assim dizer, a constante" (JENNY, 1979, p. 5).

Nesse presente artigo, buscaremos analisar brevemente como The Penelopiad efetua uma re-visão da Odisseia de Homero - na perspectiva de Adrienne Rich e Gilbert e Gubar -, desarticulando sentidos patriarcais tradicionais em relação a Odisseu, Penélope e às escravas enforcadas. Transgressão, transformação, recriação - tudo implicado na ideia de re-visão - compreendem o projeto revisionista de Atwood e são os elementos que buscaremos levantar e analisar. 


\section{A KLEOS E O NOSTOS DE ODISSEU: O PAPEL DE PENÉLOPE NA EPOPEIA HOMÉRICA}

Gregory Nagy (2013, p. 9), em seu substancial estudo sobre o herói da Grécia Antiga, The Ancient Greek Hero in 24 Hours, dispõe que, ao compor a Ilíada e a Odisseia, Homero cria uma síntese cultural do mundo grego - que era caleidoscópio na grande variedade de póleis gregas. Uma identidade cultural única é forjada para os helenos através de um processo de síntese das percepções variadas de realidade nas diferentes cidades-Estado. Cada qual traz, em sua trama central, a caracterização de um herói principal, que se destaca em meio a muitas outras figuras heroicas de importância secundária. Há histórias curtas e a história principal: micronarrativas comprimidas e a macronarrativa expandida. Na Ilíada, Aquiles é o herói de destaque. Figura monolítica, esse grande guerreiro se destacava pelas suas grandes proezas marciais. Na Odisseia, por outro lado, é o inteligente e estrategista Odisseu - como o próprio nome indica - o herói mais importante.

Aquiles é o melhor guerreiro. Sua glória é conquistada mediante a escolha do herói pela morte em combate. Odisseu é o mais inteligente. Ele é glorificado por sobreviver à guerra e às aventuras no mar e retornar para casa. Portanto, 
Aquiles e Odisseu configuram dois modelos distintos de heróis épicos. Para compreender a singularidade de cada um, há que se abordar os conceitos de kleos e nostos. Kleos é a palavra que, no universo mítico clássico, remete à glória, à fama, ao que é cantado. O conceito de kleos é usado na poesia grega para falar dos heróis de um passado distante: cantar a glória de tais heróis (NAGY, 2013, p. 26). Nostos, por sua vez, é o vocábulo que indica o retorno ao lar, a música sobre o regresso à casa $(2013$, p. 275).

A kleos do herói faz com que ele viva para sempre, por ser cantado pela épica. Assim nessas produções, o desejo de fama é sempre evidente. $O$ belo guerreiro Aquiles opta por viver uma vida curta e morrer em glória em vez de ter uma existência longa e anônima (SACO, 2018, p. 168). A llíada é o canto que garante a kleos de Aquiles. Morrer valorosamente em combate faz com que ele se transforme no herói principal desse poema épico. A kleos de Aquiles só pode acontecer, todavia, se o seu nostos não se efetivar. Sobreviver à Guerra de Tróia não traria a kleos para Aquiles. Odisseu, por outro lado, vive uma situação diametralmente oposta. Na llíada, essa personagem não pode ganhar a kleos, já que ali o herói central é Aquiles. É somente com um novo canto que Odisseu pode obter a glória. A kleos que Odisseu alcançará na Odisseia, diferentemente do ocorrido com Aquiles, depende 
de seu nostos. Somente após passar por muitos anos de múltiplas aventuras pelo mar e, finalmente regressar ao lar, Odisseu adquire a sua kleos - que é eternizada pelo canto. E esse regresso depende da inteligência de Odisseu - a sua marca distintiva. Vemos, desse modo, que Aquiles representa a figura do herói belo corajoso e guerreiro, enquanto Odisseu é o herói astuto e inteligente, que vive muito, morre velho e ganha fama (SACO, 2018, p. 168).

$\mathrm{Na}$ Odisseia, diferentes tipos de enredo e caráter são relacionados com Odisseu. Nessa épica há, de acordo com Nagy (2013, p. 276), muitos tipos diferentes de Odisseu e muitos tipos diferentes de odisseia nas micronarrativas que compõem a macronarrativa. Ele é o "homem versátil", aquele que pode mudar quem é de diferentes maneiras, o que contrasta fortemente com o caráter monolítico de Aquiles. Entretanto, a kleos que Odisseu adquire não deriva apenas de sua astúcia e de suas proezas durante as viagens marítimas. Na Odisseia, encontramos a seguinte passagem, que traz uma fala de Agamenon comparando sua situação à de Odisseu, após o final da Guerra de Tróia e o regresso para a terra natal:

És venturoso, ó solerte Odisseu, de Laertes nascido, por teres tido uma esposa dotada de tanta virtude!

Que coração bem-formado possuía a prudente Penélope, filha de Icário, que nunca esqueceu ao legítimo esposo! 
A fama dessas virtudes jamais há de ser esquecida, pois em louvor da prudente Penélope os deuses, por certo, hão de inspirar aos mortais inefáveis e eternas cantigas.

Não concebeu, como a filha de Tíndaro, ações reprováveis, para matar o marido, o que odiosas canções, certamente, há de fazer entre os homens surgir, e lançar nas mulheres

mancha indelével, em todas, até nas que forem virtuosas.

(Odisseia, XXIV, v.192-202, grifos nossos)

Nagy (2013, p. 283), analisando esse fragmento, fala do olbios de Odisseu. Penélope auxilia Odisseu a se tornar olbios - abençoado, afortunado - pois, quando ele volta para casa (nostos), a glória (kleos) se concretiza. Ítaca não foi tomada por um novo rei, apesar de ter suas riquezas em grande parte dilapidadas, e Penélope conseguiu, com suas tramas, enredar os pretendentes e manter o reino seguro até o retorno do esposo. Pelos estratagemas de Penélope, ao voltar, Odisseu mantém a posição de soberano em Ítaca e mata os pretendentes, com o auxílio de Atena. Assim, "a chave para seu (Odisseu) nostos bem-sucedido é a fidelidade constante da sábia esposa Penélope, que, por seu próprio direito, compartilha com Odisseu a kleos que marca o herói quando chegamos ao final da Odisseia" (NAGY, 2013, p. 283, tradução nossa). 
A kleos de Odisseu é partilhada por Penélope, por ela se manter "prudente" e no caminho da virtude, não esquecendo nunca do marido e protegendo o reino dos seus inimigos. A visão positiva de Penélope, como se pode ver, dá-se através de um julgamento masculino. A rainha é julgada segundo o que o patriarcado estipula como sendo a prudência e a virtude para as mulheres. É a fala do homem que faz a deliberação final - conforme os seus parâmetros - e também é ela quem estabelece a kleos de Penélope. Mantendo-se fiel e usando a sua excepcional inteligência para ludibriar os pretendentes - possibilitando, com isso, o nostos de sucesso de Odisseu -, Penélope ganhará sua kleos, que não é somente a glória, mas a canção sobre a glória. Assim, a kleos de Penélope é a sua visão de mulher prudente e virtuosa, que será cantada pela épica. Possuidora de características comportamentais validadas como positivas no discurso patriarcal, a inteligência de Penélope, dessa forma, está a serviço dos interesses do universo masculino.

Situação contrária é a de Clitemnestra. À filha de Tíndaro, em situação oposta à de Penélope, é negada a kleos. Ela será cantada em "odiosas canções", pois cometeu "ações reprováveis" segundo o discurso patriarcal. Como a Eva do universo cristão, Clitemnestra é tida como aquela que lega "mancha indelével" sobre as mulheres, em virtude de 
conspirar contra o marido Agamênon. A perda de kleos de Agamenon e a não concretização do nostos bem-sucedido são vistos, nessa perspectiva, como responsabilidade da esposa, que planejou a sua morte.

Os papéis de Penélope e Clitemnestra - o aspecto positivo da mulher na primeira e o odioso na segunda - não são exclusivos da épica homérica. A crítica literária feminista analisou as figurações da mulher desde os primórdios da tradição literária ocidental, apontando que as mulheres sempre apareceram nas produções artísticas masculinas segundo a dicotomia anjo/monstro, como veremos a seguir.

\section{AS FIGURAÇÕES DO FEMININO NA TRADIÇÃO LITERÁRIA OCIDENTAL E A PRÁTICA DA RE-VISION}

Virginia Woolf, no ensaio A Room of One's Own, publicado pela primeira vez em 1929, chamou a atenção para uma tônica presente na tradição literária ocidental: figurações do feminino que se pautavam sempre em determinados papéis cristalizados para as mulheres. Woolf observou que as personagens femininas apresentavam "extremos impressionantes de beleza e horror, a alternância entre bondade celestial e depravação demoníaca - porque assim as enxergaria um amante, conforme seu amor aumentasse ou diminuísse" (2014, p. 120). Criadas majoritariamente por 
homens, as poéticas patriarcais existentes sentenciavam as mulheres a formas específicas de figuração, que veiculavam o que os homens pensavam sobre elas (GILBERT; GUBAR, 2000, p. 11).

Os escritores homens projetaram a respeito do feminino a partir de uma concepção idealizada - de um lado a imagem que esperavam das mulheres e do outro o que temiam em relação a elas: as figuras de anjo e de monstro. Expectativa e temor, dessa forma, marcam as imagens femininas na arte. O texto de autoria masculina funciona, então, como um espelho patriarcal, onde estão inseridas as imagens ditadas em torno do feminino (GILBERT; GUBAR, 2000, p. 51).

As figurativizações de anjo e monstro são, por conseguinte, as imagens criadas pelo patriarcado sobre as mulheres ao inseri-las no espelho - texto/discurso - e representam os mais fortes ícones oferecidos a elas pela tradição literária. O anjo remete à construção idealizada de comportamentos que devem ser buscados pela mulher, em outras palavras, é o que o patriarcado espera dela: docilidade, passividade, abnegação, domesticidade, obediência. Às mulheres não seguidoras de tal imagem modelar da mulher-anjo resta a alcunha de mulher-monstro, aquela a buscar ação e independência por não se contentar em ser objeto (GILBERT; GUBAR, 2000, p. 34). 
Através da moral modelar em torno do feminino, ficava estabelecido os valores que deveriam servir de exemplo para todas as mulheres - valores a serem seguidos, no caso da figura da mulher-anjo, ou comportamentos que deveriam ser evitados, no caso da mulher-monstro. Assim, a mulheranjo configura-se enquanto uma representação ficcional de uma moral elevada a ser buscada pelas mulheres, e consequentemente, delas exigida. À mulher-monstro resta o lado negativo, o aspecto demonizado do feminino, aquele do qual as mulheres devem, obrigatoriamente, se desviar, pois, do contrário, é a morte - física pela Lei, simbólica pelas Artes em geral - que Ihes espera, segundo o discurso patriarcal. Os usos e funções na construção das máscaras míticas de anjo e monstro espelham o que todo autor patriarcal faz com as mulheres que destoam do padrão escolhido pelo patriarcado para ser seguido pelas mulheres (submissão/silenciamento/ docilidade): ele enfatiza sua monstruosidade, o que o autoriza a puni-la de acordo com as Leis patriarcais.

Em suma, diante do espelho (texto/discurso), as mulheres deveriam buscar reconhecimento. Contudo, a definição do feminino ali presente representava não o que elas eram, mas o modo como foram idealizadas pelos homens, o que deveriam ser. O espelho patriarcal funcionava então como 
uma prisão que atrapalhava a busca das mulheres por definirem a si mesmas, inibindo a força criativa e criando hesitação nas escritoras.

O controle da pena pelas mãos de escritores homens não reflete só uma importância em nível artístico. Muito mais que isso, a pena pode ser compreendida como um símbolo do poder exercido pelo homem - o poder de ditar o que é o feminino e sentenciar qual é o seu lugar na arte e também no mundo. A luta das mulheres pela autoria não é algo de pequena importância, pois discurso e poder combinam-se. Como postulado por Michel Foucault,

por mais que o discurso seja aparentemente pouca coisa, as interdições que o atingem revelam logo, rapidamente, sua ligação com o desejo e com o poder. Nisto não há nada de espantoso, visto que o discurso - como a psicanálise nos mostrou - não é simplesmente aquilo que traduz as lutas ou os sistemas de dominação, mas aquilo porque, pelo que se luta, o poder do qual nos queremos apoderar. (2014, p. 9-10)

A interdição é o projeto mais evidente de exclusão da posse do discurso. Historicamente, a mulher teve o direito ao discurso negado, porém, quando as escritoras passaram a se envolver ativamente com a atividade literária, vemos que, além da interdição, existem outras formas de controle e 
limitação do discurso no seio da sociedade patriarcal. Tomar a pena significou ter o poder de não ser objeto passivo do discurso do outro, bem como implicou numa nova luta. As estratégias de manutenção da relação de poder de homens sobre mulheres não se basearam somente nas coerções do discurso - "as que limitam seus poderes, as que dominam suas aparições aleatórias, as que selecionam os sujeitos que falam" (FOUCAULT, 2014, p. 35) -, mas também no uso de representações deformadas do feminino impostas às mulheres, que atuaram na naturalização da noção de inferioridade delas - o que implicava a ideia de que a mulher, sendo uma criatura de segunda importância, produzia uma escrita que não poderia ser igualada àquela dos escritores homens.

A escrita serviu como forma de aprisionar as mulheres. Isso ocorreu por meio das formas preconcebidas que eram prescritas sobre elas pelos escritores homens, pois, "o que escraviza não é a escrita em si, mas o controle da escrita ou a escrita como controle" (JOHNSON, 1995, p. 47, tradução nossa). A interdição do discurso às mulheres representou tanto uma forma de controle masculino sobre a escrita ditar quem está autorizado a falar - como o controle do que a escrita fala - os textos de autoria masculina veiculando as visões do homem sobre si, sobre o mundo e sobre as 
mulheres. Assim, o controle da escrita e a escrita como controle reprimem e sentenciam o feminino.

De posse do discurso, as mulheres tiveram que lutar contra a limitação que era imposta ao que elas podiam dizer. Como herdeiras dos frutos da luta de suas antecessoras, muitas escritoras do século XX puderam ir adiante e não só fazer a revisão da imagem da essência feminina que existia nos textos patriarcais, mas reinventar as histórias originais e as figuras femininas tradicionais da mitologia patriarcal, como Circe, Leda, Cassandra, Medusa, Helena e Perséfone (GILBERT; GUBAR, 2000, p. 80).

\section{THE PENELOPIAD E A PRÁTICA DA RE-VISÃO: RELENDO O FEMININO PRESENTE NOS TEXTOS PATRIARCAIS}

Como visto anteriormente, na Odisseia, Penélope figura como aquela que auxilia a jornada do herói. Clitemnestra, pelo contrário, planeja a morte do marido. A "prudente" Penélope, portanto, dá uma boa reputação às mulheres, enquanto Clitemnestra, mulher de "ações reprováveis", gera uma visão negativa do feminino. Elas se tornam exemplos morais do que era tido como correto e reprovável do ponto de vista dos homens.

Pierre Grimal , em seu Dicionário da Mitologia Grega e Romana, aponta outra faceta de Penélope, presente no ciclo pós-homérico, com 
[...] tradições relativas aos amores adúlteros de Penélope e às suas aventuras após o regresso de Ulisses. Entre as histórias dos amores ilícitos da heroína, figura nomeadamente a lenda segundo a qual ela teria ido cedendo sucessivamente aos cento e vinte e nove pretendentes e teria concebido o deus Pã, como fruto de tais amores. Conta-se ainda que Ulisses, ao regressar, se apercebera da infidelidade de Penélope e tê-la-ia repudiado. Ela fora então para Esparta, donde partira depois rumo a Mantineia, onde viria a morrer e a ser sepultada. Segundo outra versão, Ulisses ter-Ihe-ia roubado a vida, para assim a punir pelos seus amores ilícitos com Anfínomo, um dos pretendentes. (2014, p. 9-10)

Em The Penelopiad, livro publicado originalmente em 2005, a escritora canadense Margaret Atwood seleciona um fragmento da Odisseia - o enforcamento das doze escravas após o retorno de Odisseu a Ítaca - para desenvonver a sua re-visão. Atwood, contudo, também dialoga com as outras versões sobre a esposa de Odisseu, presente na tradição pós-homérica. Contrariamente ao que o título pode dar a entender, na odisseia de Penélope à espera do retorno do marido, o novo contar não é exclusivamente sobre a sua vida. As epígrafes de abertura da narrativa - dois trechos da Odisseia - deixam claro o objetivo revisionista e trazem o conflito que será posto ao longo da obra - a tensão figurada 
em uma narração que é divida entre Penélope e as doze escravas enforcadas, que formam o Coro.

Industrioso Odisseu, grande era o mérito da que tomaste por esposa. Nobres os sentimentos da irrepreensível Penélope, filha de Icário, que soube manter- se sempre fiel a seu esposo Odisseu! Por isso, jamais perecerá a fama de sua virtude, e os Imortais inspirarão aos homens belos cantos em louvor da prudente Penélope (CANTO XXIV). Tomou a corda de uma nau de escura proa, e retesou-a à altura da grande coluna em volta do pavilhão, de sorte que os pés não pudessem tocar no solo. Do mesmo modo que os tordos de larga envergadura ou as pombas tombam numa armadilha disposta sobre uma sarça - leito funesto - quando voltam para o ninho, assim as mulheres, alinhadas e com um nó corredio em volta do pescoço, sofriam horrorosa morte. Seus pés se agitaram uns instantes, e tudo acabou. (CANTO XXII)

A escolha de ambos os trechos da Odisseia para abrir o livro não é arbitrária, como nada na criação literária ocorre sem intencionalidade. A primeira epígrafe remete à visão que a tradição criou em torno de Penélope, que, como já foi citado, se relaciona com uma cristalização do feminino pautado na ideia de mulher ideal, servindo como modelo moral a ser seguido pelas outras mulheres. A segunda traz o episódio do enforcamento das escravas. Sobre a tradição 
de que se valeu e as escolhas feitas por ela na criação da sua narrativa, a autora dispõe:

Usei material diferente da Odisseia, principalmente para obter detalhes a respeito da família de Penélope, de sua vida de solteira e do casamento, além dos rumores escandalosos que circulavam a seu respeito. Optei por entregar a narrativa a Penélope e às doze escravas enforcadas. As escravas formam o Coro, que canta e declama, concentando-se nas duas questões que se destacam numa leitura atenta da Odisseia: o motivo do enforcamento das escravas e o real propósito de Penélope. A maneira como a história é contada na Odisseia não convence, há muitas incoerências. Sempre vivi assombrada pelas escravas enforcadas; em The Penelopiad, ocorre o mesmo com Penélope. (ATWOOD, 2005, p. 12-13, tradução e grifos nossos)

Atwood alude à tradição canônica - a épica homérica -, que foi responsável por legar a imagem que temos hoje de Odisseu e Penélope: o herói ardiloso que viveu uma vida de aventuras, sempre sagaz e cheio de truques, e sua esposa perfeita e fiel que tinha como marca distintiva a constância e a inteligência demonstradas ao ludibriar os pretendentes à sua mão. A escritora, entretanto, atenta para o fato de que a origem dessas histórias míticas remete às tradições locais, de cunho oral, o que fez com que mudanças fossem criadas quando as histórias eram contadas por diferentes contadores 
e em diferentes lugares. Com isso, ainda que a versão de Homero seja aquela que permanecerá para a posteridade, existiram outras variantes que também contavam sobre os mesmos acontecimentos, trazendo novas formas de figuração para essas personagens e novos sentidos para o enredo.

Insatisfeita com a versão presente na epopeia clássica, sobretudo quanto ao episódio do enforcamento das doze escravas, Atwood se propõe a criar sua produção revisionista numa trajetória à margem dessa narrativa, que é um dos pilares da tradição literária ocidental, relacionando a herança legada pela Odisseia com os aspectos menos abonadores de Penélope, presentes em outras versões do mito. The Penelopiad, portanto, tem início com a tomada da voz, por parte da escritora, para dizer o que a incomoda na tradição e a motiva a produzir uma outra versão.

Após a fala da escritora, colocando-se como porta voz do novo contar, a obra tem o começo propriamento dito. É a vez da narradora Penélope reivindicar a palavra e criar a sua versão da história - história esta que sempre fora contada pela voz do outro, o homem. Do Hades, muitos séculos depois dos acontecimentos narrados, Penélope conta que Odisseu sempre fora um rematado mentiroso, mas se mostrava ressentida pelo fato de que ele também mentia para ela, 
bradando: "Não fui fiel? Não esperei, e esperei, e esperei, apesar da tentação - quase compulsão - de desistir? E o que me restou, quando a versão oficial se consolidou? Ser uma lenda edificante. Um chicote para fustigar outras mulheres" (ATWOOD, 2015, p. 16, tradução nossa).

Essa fala de Penélope chama a atenção por dois fatores distintos. Ela fala que a "versão oficial" consolidou uma imagem de si que servia para controlar as mulheres. Rebelando-se contra isso, Penélope diz, logo na sequência:

Por que não podem todas ser tão circunspectas, confiáveis e sofredoras como eu? Era essa a abordagem que adotavam os cantores, os rapsodos. Não sigam meu exemplo, sinto vontade de gritar nos ouvidos de vocês - sim, nos de vocês! Mas, quando tento gritar, pareço uma coruja! (ATWOOD, 2005 , p. 16, grifos da autora, tradução nossa)

A ideia de "versão oficial" se desdobra quando consideramos a segunda epígrafe. Enquanto a primeira delas fala de Penélope, uma mulher exemplar que viveu pelo dever para com seu marido, a segunda epígrafe traz o episódio do enforcamento das doze escravas, por ordens de Odisseu, por terem supostamente auxiliado os pretendentes à mão da rainha durante a longa permanência destes no reino de Ítaca. Logo após Penélope iniciar a narrativa, propondo-se a tecer sua própria história, em oposição à fala oficial masculina, as 
escravas tomam a voz sob a forma do Coro, criando, também, uma nova voz e perspectiva diante da tradição.

Somos as escravas

Que vocês mataram

Que vocês traíram

Dançamos leves

Pés descalços no ar

No injusto balançar

[...]

Dançamos no ar

As escravas que vocês

Traíram e mataram. (ATWOOD, 2015, p, 18-

19 , tradução nossa)

Denunciando o cruel destino que sofreram por ordens de Odisseu, as escravas falam em trair e matar. Sabemos de antemão quem as matou - Telêmaco as enforcou com o consentimento do pai -; todavia, a traição se relaciona com qual personagem? Como escravas, essas mulheres não tinham poder sobre suas vidas e seus corpos. Ao longo de The Penelopiad, a narração - dividida entre Penélope e o Coro - dá a saber que as dozes servas de confiança de Penélope se aproximaram dos pretendentes para ajudar a rainha a saber dos planos deles. Depois, quando Odisseu retorna, Penélope nada faz para salvar as suas ajudantes, por medo de comprometer a sua reputação.

Quando toma a pena e conta a própria história, Penélope inicia sua re-visão da tradição falando como representante 
da classe senhorial. Mortas sem direito de defesa, resta às escravas formar o Coro e bradar a sua inocência, expondo sua condição de classe subalterna e dissonante. The Penelopiad dialoga com o texto homérico explicitamente seguindo uma perspectiva do século XXI. É de muitos séculos depois dos acontecimentos descritos que essas mulheres irão falar. Momento em que é possível propor outras figurações tanto de Penélope como das escravas.

A re-visão é a escrita que nasce de uma leitura prévia. Não se trata, porém, de ler o passado com os olhos de hoje. O percurso é outro. A nova versão transforma a matriz a partir de um novo momento de produção. A escrita é o resultado de reflexões no tempo presente, que se inserem na narrativa anterior como um palimpsesto. The Penelopiad, nessa chave interpretativa, traz a epopeia homérica para os dias hodiernos e re-visa a tradição valendo-se das experiências contemporâneas. Ao mesmo tempo, dialoga tanto com o papel da mulher na literatura e na sociedade da Grécia Antiga, como com as formas de sociabilidade vividas por elas no século XXI.

Nessa relação temporal - passado e presente -, a literatura está em íntima conexão com o seu momento histórico. Em The Penelopiad, entretanto, a realidade social 
funciona não apenas como tema, ela se transforma em componente da narrativa. Em outras palavras, os aspectos sociais são elementos que formam a estrutura estética do texto. A análise, desse modo, requer uma interpretação de texto e contexto de forma indissociável, entendendo que "o externo (no caso, o social) importa, não como causa, nem como significado, mas como elemento que desempenha um certo papel na constituição da estrutura, tornando-se, portanto interno" (CANDIDO, 2011, p. 13-14).

Tal fenômeno, chamado de redução estrutural pelo crítico literário Antonio Candido (1970), requer do analista literário o entendimento da função da realidade social na obra enquanto elemento integrante de sua estrutura, e, também, prevê que a análise literária reflita sobre o modo de formalização dos dados externos a fim de uma compreensão adequada da maneira como as relações sociais de um período ordenam - e, ao mesmo tempo, formam - a narrativa. Ainda sobre isso, Roberto Schwarz (1990) dispõe que, nessa correspondência entre estilo e sociedade, o escritor trabalha com um material que excede a literatura, a fim de criá-la. Os problemas estéticos, nessa perspectiva, estão relacionados com a História intra e extra-artística, pois "esta é a virtude da forma, ela atravessa a obra literária 
e percorre também a sociedade" (SCHWARZ, 1990, p. 31). A forma, desse modo, relaciona-se com a cultura e não se reduz somente à linguagem.

Em The Penelopiad a economia interna se organiza através da transposição para o estilo da busca da mulher na contemporaneidade por autonomia e voz, num processo de construção da identidade e da experiência feminina. $O$ jogo de vozes - com Penélope e o Coro de escravas - atualizam o mito num contexto em que a mulher pode não só reivindicar o direito de falar de si, como contestar o que é dito sobre ela. A multiplicidade das vozes que narram põe em xeque a ideia de uma essência feminina e da experiência da mulher como algo singular.

Ademais, as escravas questionam a legitimidade do que Penélope fala. Sendo a arte capaz de problematizar as relações de poder na sociedade, a construção narrativa em The Penelopiad traz à baila o conflito de poder entre as mulheres de diferentes estratos sociais. A fala principal é de Penélope. As escravas só conseguem ter voz usando o subterfúgio do Coro. Elas sussurram suas desventuras, num ato de denúncia, mas o discurso oficial pertence a uma mulher da classe senhorial. Com isso, enquanto Penélope re-visa a tradição literária patriarcal, as escravas contestam a versão da rainha. 
Como observa Sigrid Renaux (2009, p. 139-140) a subversão da tradição em The Penelopiad se dá mediante duas estratégias narrativas. A primeira delas é a ausência do lugar e da autoridade dos homens na voz que fala, desnudando e desarticulando a natureza patriarcal da mitologia grega. $O$ segundo ponto que instaura a diferença em relação à tradição é a desarticulação do gênero épico:

Ampliando-o e adaptando-o a sua própria época - a da pós-modernidade, com suas convenções culturais e sociais - ao tornar uma história não ilustre o assunto da epopeia [...]. Subverte, simultaneamente, o meio expressivo da poesia épica - caracterizado pelo emprego do hexâmetro dactílico como estrutura métrica mais conveniente -, ao introduzir, além da prosa nos capítulos narrados por Penélope, também outras formas literárias e composições poéticas nos capítulos cantados, declamados ou narrados pelo Coro [...]. (RENAUX, 2009, p. 140-141)

Filha do século $X X I$, a obra responde a uma tradição de silenciamento da mulher. Desse modo, o falar de si na contemporaneidade dialoga com um passado funesto. Porém, bastaria que apenas Penélope narrasse para desarticular a tradição literária patriarcal e trazer a alteridade da mulher. Dar voz às escravas, problematiza o próprio lugar de fala feminino. O Coro de escravas fala, mas elas são ouvidas? Assim, vê-se que o livro de Atwood aborda o diálogo com a 
tradição e o feminino, num mundo que já não é o de antes, mas que não deixa de estabelecer conexões entre as novas dinâmicas e as práticas tradicionais. O ser mulher pode ser entendido como estado de intersecção entre o passado e o presente - o que ocorre hoje se relaciona com práticas do passado nem sempre superadas, já que nem todas as mulheres que agora falam são ouvidas, e seu discurso muitas vezes carece de legitimidade perante a sociedade.

O silêncio de Penélope, não contando para Odisseu e mais ninguém que as escravas agiam em seu nome, indica a ambivalência dessa personagem e traz um perfil que destoa das imagens de prudência e virtude legadas pela tradição. Penélope tinha o poder de escolha, algo negado às escravas; ainda assim, como só ela tinha voz, e optou por calar e não falar a verdade, ela trai suas benfeitoras.

Por vezes, Penélope usa de falas ambíguas que suscitam desconfiança quanto à sua fidelidade a Odisseu, bem como aventam a possibilidade de que ela possa ter se calado sobre as escravas para que não fosse revelado um suposto relacionamento escandaloso mantido com os pretendentes, algo conhecido apenas pelas moças. No retorno de Odisseu, Penélope narra as mentiras que ambos contaram:

Ele me disse quanto sentira minha falta e quanto desejava retornar para mim, mesmo 
quando estava nos alvos braços das deusas. Eu falei das lágrimas copiosas que derramara enquanto esperava por ele vinte anos, e que eu fora fiel apesar de tudo. Jamais seria capaz sequer de pensar em trair sua cama gigantesca e a coluna especial, dormindo ali com outro homem. Nós dois éramos mentirosos rematados, desavergonhados e confessos de longa data. Chega a admirar que tenhamos acreditado nas palavras um do outro. Mas acreditamos. Ou foi o que dissemos um ao outro. (ATWOOD, 2005, p. 138 , tradução nossa)

Como essa passagem deixa ver, Penélope nunca afirma explicitamente que não fora fiel durante a ausência do marido, mas mantém essa possibilidade em aberto através de um discurso sempre ambíguo. Assim, quando Odisseu retorna, a morte dos pretendentes marca o extermínio da ameaça de mácula de sua virtude. Entretanto, como as escravas, ainda que criaturas sem voz nessa sociedade, sabiam de todos os seus passos - conforme Penélope dá a entender em suas falas, sempre enigmáticas, sobre o episódio -, a sua morte também convinha para a manutenção da imagem de decoro da esposa de Odisseu.

Vemos, desse modo, que, quando Penélope toma a voz para contar a sua versão da história, não se trata apenas de uma mulher re-visando as imagens sobre o feminino criadas na tradição. Ao contrário, Penélope joga com a narração e deixa 
ver que suas ações não foram tão virtuosas como cantadas pela épica, ao mesmo tempo em que reforça a versão que a exalta como exemplo de fidelidade e prudência ao exercer a autoridade senhorial para falar, calando as servas. O Coro, no entanto, consegue se inserir nessa nova versão oficial - agora não mais a do homem, mas a da mulher da classe senhorial - e denunciar uma outra história diferente, a partir da perspectiva das escravas. As falas do Coro indicam que falar do feminino, tomando a categoria "mulher" como de caráter singular, é um erro, pois o ser mulher é algo múltiplo. Penélope toma a voz e cria sua história de um ponto de vista de uma mulher; entretanto, esse ponto de vista não é o mesmo das mulheres subalternas, e não traduz interesses similares.

Assim, nesse livro, a kleos de Penélope - a visão positiva que se cantou sobre ela desde o mundo antigo - é posta à prova. A kleos e o nostos de sucesso de Odisseu também são desarticulados, pois, em virtude do assassinato das escravas, Odisseu seguirá eternamente perseguido pelos espíritos dessas mulheres, vivendo em desgraça. É importante ressaltar que Odisseu - o herói por excelência da Odisseia homérica - é coadjuvante em The Penelopiad e pouco aparece. Nada da astúcia e da inteligência do herói homérico é posto em relevo. Odisseu é apenas um mentiroso 
renomado, que volta para casa após muitos anos no mar, exterminando os pretendentes e ordenando a morte cruel e sem defesa das escravas.

\section{CONSIDERAÇÕES FINAIS}

Em The Penelopiad, a tomada da pena pela mulher representa não apenas a possibilidade da construção da identidade e experiência feminina, mas também a problematização da própria categoria "mulher". As manifestações literárias, enquanto práticas sociais, estão conectadas com o momento histórico de sua emergência - manifestadas em sua tessitura. A dupla narração na obra de Atwood, que se relaciona com a multiplicidade de realidades para as mulheres na contemporaneidade, desempenha um papel na constituição da estrutura da narrativa. O externo se torna interno, como dispõe Antonio Candido (2011).

Giorgio Agamben (2009), postula que ser contemporâneo é possuir uma relação especial com o tempo e com o passado. Contemporâneo é aquele capaz de fraturar as vértebras do seu tempo, ao perceber a falha. The Penelopiad efetua o mesmo movimento ao mostrar que o feminino é múltiplo, numa realidade em que nem todas as mulheres são tratadas da mesma forma. Penélope toma a pena e conta a sua história, como não o poderia no tempo de Homero; contudo, 
a voz das escravas ainda permanecem como um Coro que tenta se fazer ouvir, e permanece posto de lado. Vendo as trevas do seu presente, a re-visão de Atwood traz o espírito do contemporâneo ao mostrar, de maneira perspicaz, que o avanço dos direitos das mulheres não chegou para todas. A duplicidade de Penélope, uma narradora em primeira pessoa que não esconde seus vestígios de ambivalência, é característica da literatura pós-moderna. A contradição, o incerto e o não fechamento de sentidos são marcas desse tipo de narrativa.

Como já dito, a literatura mantém relação próxima com seu contexto de produção. A imagem do herói da Odisseia respondia a um tipo específico de civilização, traduzindo anseios e pontos de vista dos helenos. A figura da mulher, nesse momento, era julgada e sentenciada segundo a perspectiva e a fala dos homens. Dessa forma, a virtude e a prudência de Penélope relacionam-se com a fidelidade ao marido que estava longe e ao uso de sua inteligência para manter o reino seguro até o regresso de Odisseu. The Penelopiad, por outro lado, é filha do século XXI e posterior às lutas e avanços conquistados pelo movimento feminista. O enredo homérico é re-visado a partir do ponto de vista dos dias hodiernos, considerando que o conceito 
de "mulher" no singular é uma redução e não dá conta de traduzir a multiplicidade de vivências, realidades e anseios das mulheres. A subalternidade das escravas responde não só a uma questão de gênero, já que Penélope é mulher e está autorizada a recontar a sua vida e criar uma outra narrativa-mestra. As relações entre mulher e patriarcado, na nova leitura, exige que também se vislumbre a questão da classe social.

The Penelopiad põe em xeque as virtudes de Penélope, inscritas na tradição homérica. Os truques de Penélope - am ambos os textos - visam a objetivos distintos. Na Odisseia, Penélope usa de estratégias variadas para conseguir ludibriar os pretendentes e se manter fiel e prudente, ou seja, sua astúcia está a serviço do patriarcado. Em The Penelopiad, por outro lado, os atos da rainha visam sempre à manutenção de uma moral ilibada diante da opinião pública. Dessa forma, a re-visão da tradição empreendida nessa obra requer uma análise paralela do texto novo com a matriz de origem. As mudanças significam de duas formas: elas tanto evidenciam práticas e discursos inerentes ao mundo grego antigo inscritos no texto homérico, como indicam que a diferença criada na narrativa do século XXI responde a um contexto e a demandas novas, próprias de seu tempo. Valendo-se do mesmo enredo presente na Odisseia, Atwood desarticula a 
canção sobre o herói homem em The Penelopiad, trazendo, também, a voz das mulheres silenciadas na tradição e mostrando que, em seu contar, essas mulheres podem enredar e manipular, como o faz Penélope.

O patriarcado não é fixo. O ser homem e o ser mulher - e as relações entre ambos - estão sujeitos às mudanças sociais que ocorrem com a passagem do tempo. Re-visar é criar no agora - figurando tensões do presente - e não apenas uma nova visão sobre o passado. The Penelopiad traz a um só tempo a luta contra a poética e a opressão patriarcal e a tomada de voz e as figurações do feminino conectadas com a dinâmica do ser mulher nos dias hodiernos. A leitura do passado não se dá apenas para que as escritoras possam tomar a pena e recriar as imagens cristalizadas da mulher na tradição. A revisão crítica da tradição feita pelas escritoras mulheres se relaciona com o momento presente, quando elas manifestam em sua arte uma nova realidade social em relação àquela vivida por suas antepassadas.

\section{REFERÊNCIAS}

AGAMBEN, Giorgio. O que é o contemporâneo? e outros ensaios. Tradução de Vinícius Nicastro Honesco. Chapecó: Argos, 2009. ATWOOD, Margaret. The Penelopiad: The Myth of Penelope and Odysseus. Toronto: Vintage Canada, 2005.

BLOOM, Harold. Um mapa da desleitura. Tradução de Thelma Médici Nóbrega. Rio de Janeiro: Imago, 2003. 
CANDIDO, Antonio. Dialética da malandragem. Revista do Instituto de estudos brasileiros, n. 8, p. 67-89, 1970.

CANDIDO, Antonio. Literatura e sociedade. Rio de Janeiro: Ouro sobre Azul, 2011.

FOUCAULT, Michel. A ordem do discurso. Tradução de Laura F. de Almeida Sampaio. 24. ed. São Paulo: Edições Loyola, 2014.

GILBERT, Sandra M.; GUBAR, Susan. The Madwoman in the Attic. The Woman Writer and the Nineteenth-Century Literary Imagination. 2. ed. New Haven (CT); London: Yale University Press, 2000.

GRIMAL, Pierre. Dicionário da mitologia grega e romana. Tradução de Victor Jabouille. Rio de Janeiro: Bertrand Brasil, 2014.

HOMERO. Odisseia. Tradução de Carlos Alberto Nunes. 25. ed. Rio de Janeiro: Nova Fronteira, 2015.

JENNY, Laurent. A estratégia da forma. In: JENNY, Laurent et al. Intertextualidades. Coimbra: Almedina, p. 5-49, 1979.

JOHNSON, Barbara. Writing. In: LENTRICCHIA, Frank; McLAUGHLIN, Thomas (Ed.). Critical Terms for Literary Study. 2. ed. Chicago (IL); London: The University of Chicago Press, 1995.

NAGY, Gregory. The Ancient Greek Hero in 24 Hours. Londres, The Belknap Press of Harvard University Press, 2013.

RENAUX, Sigrid. Da Odisseia à Odisseia de Penélope: o coro de escravas como porta-voz da alteridade violência e redenção. Revista Letras, v. 77, p. 139-166, 2009.

$\mathrm{RICH}$, Adrienne. When We Dead Awaken: Writing as Re-Vision. College English, Urbana (IL): National Council of Teachers of English, v. 34, n. 1, October, p. 18-30, 1972.

SACO, Julio López. La configuración del héroe épico griego arcaico a través de Homero y Hesíodo. El Futuro del Pasado, n. 9, p. 157-176, 2018.

SCHWARZ, Roberto. Um mestre na periferia do capitalismo: Machado de Assis. São Paulo: Duas Cidades, 1990. 
SHOWALTER, Elaine. Toward a feminist poetics. In: SHOWALTER, Elaine. The New Feminist Criticism: Essays on Women, Literature and Theory. New York: Pantheon Books, p. 125-143, 1979.

WOOLF, Virginia. Profissões para mulheres. In: WOOLF, Virginia.

Profissões para mulheres e outros artigos feministas. Tradução de Denise Bottmann. Porto Alegre: L\&PM, p. 9-19, 2013.

WOOLF, Virginia. Um teto todo seu. Tradução de Bia Nunes de Souza, Glauco Mattoso. São Paulo: Tordesilhas, 2014.

\section{Juliana Cristina Terra de Souza}

Doutoranda em Estudos de Literatura pela UFSCar.

É membro dos grupos de pesquisa vinculados ao CNPq Diálogos Literários e Estudos do Gótico.

E-mail: julianacristinaterra@yahoo.com.br

Lattes: http://lattes.cnpq.br/9563961120440497

ORCID iD: https://orcid.org/0000-0001-6659-1542 